\title{
DISSONANCE BETWEEN FACT AND LAW: THE EXAMPLE OF VISUAL ARTISTIC PRACTICE AND INCOME TAX CONCESSIONS FOR PEAK COPYRIGHT
}

\author{
Jonathan Barrett*
}

The principal income tax statutes of both New Zealand and Australia provide special concessions for taxpayers who earn exceptional copyright income in a year of assessment. As authors (creators) of copyright-protected artistic works, visual artists are potential beneficiaries of these preferences but, because they typically produce singular artworks that are not licensed for reproduction, they cannot directly benefit from copyright or, as a consequence, tax concessions granted to copyright assignors or licensors.

In New Zealand, a taxpayer who receives peak copyright payments can opt to average those receipts over more than one assessment year. An Australian taxpayer can spread their more broadly defined assessable professional income and, if they operate a professional arts business, may enjoy an exception to the non-commercial loss rules, and so may claim net losses in the year they are incurred. The substantive provisions of neither the Income Tax Act 2007 nor the Income Tax Assessment Act 1997 (Cth) expressly incorporates provisions of copyright legislation but both taxing statutes explicitly import copyright terminology and, implicitly, concepts and doctrine.

Examination of differences between fact and law is a significant field of legal research. In taxation studies, John Prebble's identification of "ectopia" presents the best-known analysis. Prebble characterises income tax law as "ectopic" (out of place), inasmuch as it is dislocated from the facts to which it relates. Copyright law is likewise dislocated from typical artistic practice. When copyright principles are incorporated into income tax legislation, the relevant provisions may be doubly estranged from the facts to which they relate. This article, which has an Australasian jurisdictional

* Associate Professor in Taxation and Commercial Law, Wellington School of Business and Government, Victoria University of Wellington | Te Herenga Waka. 
focus but also draws on Quebecois tax legislation, investigates that possibility and considers, in particular, the consequences for equity in income taxation.

\section{INTRODUCTION}

Examination of differences between fact and law is a significant field of legal research. ${ }^{1}$ In taxation studies, John Prebble's identification and exposition of "ectopia" provides the pre-eminent analysis. ${ }^{2}$ Prebble characterises income tax law as "ectopic" (out of place) ${ }^{3}$ because: ${ }^{4}$

income tax law is, in a fundamental sense, dislocated from the facts to which it relates. One result of this

dislocation is that income tax law is and must always be fundamentally flawed.

A further consequence of this dislocation is the existence of "rules that mete out different treatment to taxpayers whose economic position is similar." ${ }^{5}$ Dissonance between fact and law can therefore lead to inequity in income taxation and breach of the related principle of neutrality. ${ }^{6}$ Economic inefficiencies may also arise if government confers concessions on certain taxpayers when no justification exists for doing so either in terms of market failure or the things transacted being socially judged as merit goods or services. ${ }^{7}$

Copyright law is also dislocated from the artistic practice of many visual artists, even though artistic works have attracted copyright protection in the British-heritage tradition since the early 19th

1 Jürgen Habermas Faktizität und Geltung: Beiträge zur Diskurs Theorie des Rechts und des demokratischen Rechtsstaat (Suhrkamp Verlag, 1992) (translated ed: William Rehg (translator) MIT Press, Cambridge (Mass), 1996) situates law between social facts and ideal Kantian norms. See also Péter Cserne "Facts and Norms in the Behavioural Assumptions of Law" in Sanne Taekema, Bart van Klink and Wouter de Been (eds) Facts and Norms in Law: Interdisciplinary Reflections on Legal Method (Edward Elgar, Cheltenham, 2016) 100; and Geoffrey Samuel "Imitation of Life: Resonances between Law and Fact and Fact and Law" in Sanne Taekema, Bart van Klink and Wouter de Been (eds) Facts and Norms in Law: Interdisciplinary Reflections on Legal Method (Edward Elgar, Cheltenham, 2016) 53.

2 For a collection of relevant papers, see "Prebble - Ectopia and fictions" Faculty of Law, Victoria University of Wellington | Te Herenga Waka <www.victoria.ac.nz>.

3 With respect, Prebble's use of the term "ectopic" and its correlatives as an allusion to ectopic pregnancy is a regrettable metaphor to connote the way in which income tax law is "pathological, serious, and incurable". See John Prebble "Ectopia, Tax Law and International Taxation" (1997) 5 BTR 383 at 383. No doubt an ectopic pregnancy manifests each of these qualities, but dissonant tax provisions are not a matter of life or death or, indeed, personal tragedy.

4 At 383

5 At 403

6 See Part IV below for an identification of usual tax criteria, including an outline of the principle of neutrality

7 On tax policy issues relating to market failure and the reward for artists, and artworks as merit goods, see Jonathan Barrett "On Artworks as Merit Goods for Tax Purposes" (2020) 2 BTR 200. 
century. ${ }^{8}$ The kinds of activities and outputs for which copyright law is most suitable (works that lend themselves to reproduction) do not reflect the artistic practice and broader lived experience of many visual artists, who typically produce singular artworks. ${ }^{9}$ The value of those things lies in their uniqueness, rather than a capacity for replication.

Artists (or their estates), ${ }^{10}$ who significantly benefit from copyright protection, may fall at either end of a spectrum of critically appraised art - Pablo Picasso, ${ }^{11}$ perhaps, at one end and Thomas Kinkade at the other. ${ }^{12}$ Between these poles, visual artists typically gain little or no direct pecuniary benefit from copyright and therefore cannot enjoy a tax advantage conferred on copyright income. ${ }^{13}$

The principal income taxing statutes of both New Zealand and Australia provide special concessions for taxpayers who earn extraordinary copyright income in a particular year of assessment. Broadly, in New Zealand, a taxpayer who receives a lump sum copyright payment for assigning or licensing their rights to another person can opt to average that receipt over more than one assessment year. ${ }^{14}$ An Australian taxpayer can spread their more widely defined "assessable professional

8 As its name suggests, the Engraving [Engravers'] Copyright Act 1734 (UK) extended copyright from printed matter to multiply replicable engravings, a comparable technology to printing. The Fine Art Copyright Act 1862 (UK) conferred copyright on works of fine art, such as paintings and sculptures. Singular paintings and engravings are technologically and ontologically different. See Jonathan Barrett "Copying Artistic Works: Copyright, Aesthetics, and Artistic Practice" in Jani McCutcheon and Fiona McGaughey (eds) The Research Handbook on Art and Law (Edward Elgar, Cheltenham, 2020) 59.

9 On the distinction between singular (autographic) creations, for example non-cast statues, and multiple (allographic) works, such as novels or musical compositions, see Nelson Goodman Languages of Art: An Approach to a Theory of Symbols (2nd ed, Hackett Publishing Co, Indianapolis, 1976) 115-118.

10 Copyright expires 50 years after the death of the author. See Copyright Act 1994 [CA 1994], s 22. In Australia the European Union and the United States, among other jurisdictions, the corresponding period is 70 years from death.

11 The copyright and droit de suite earnings of Picasso's estate are colossal. See Milton Esterow "The Battle for Picasso's Multi-Billion-Dollar Empire" Vanity Fair (online ed, United States, 7 March 2017) $<$ www.vanityfair.com>. Copyright and droit de suite in Picasso's works will not expire before 2043. See Intellectual Property Code (France), art L 123-1.

12 Despite vilification of the kitsch nature of his works by critics, Thomas Kinkade's reproductions are said to be the most collected artworks in the United States. See Alexxa Gotthardt "Thomas Kinkade, the Painter Art Critics Hated but America Loved" (10 October 2018) Artsy <www.artsy.net>.

13 Since copyright allows a copyright-holder to prevent reproduction of a unique artistic work, it provides a mechanism for ensuring scarcity and, thereby, an economic benefit. See Henry Hansmann and Marina Santilli "Authors' and Artists' Moral Rights: A Comparative Legal and Economic Analysis" (1997) 26(1) J Legal Stud 95. However, any such economic benefit does not constitute a flow of income that might be taxed under ordinary concepts (something that comes in). See ITA 2007, CA 1(2) and, for example Dawson v Commissioner of Inland Revenue (1978) 3 NZTC 61,252 (SC).

14 Income Tax Act 2007 [ITA 2007], s EI 3. 
income", ${ }^{15}$ and, if they operate a professional arts business, may enjoy an exception to the noncommercial loss rules, and so may claim net losses in the year they are incurred. ${ }^{16}$ The substantive provisions of neither the Income Tax Act 2007 (ITA 2007) nor the Income Tax Assessment Act 1997 (Cth) (ITAA 1997) specifically incorporate provisions of copyright legislation but both taxing statutes explicitly import copyright terminology and, implicitly, copyright concepts and doctrine.

When copyright law is incorporated into income tax legislation, further distance from fact is imported into the income tax system, which Prebble has identified as being inherently dislocated. ${ }^{17}$ Artists, who do not practically benefit from copyright, become doubly estranged as they are denied income tax concessions enjoyed by their copyright-earning peers, who already directly benefit from the exclusive exploitation rights over their creations conferred by copyright. ${ }^{18}$ This article does not support special income tax concessions for artists, but does argue for equitable treatment of similarly situated taxpayers, if such concessions are in fact granted.

Other usual tax criteria may also be relevant to an assessment of peak copyright and related concessions. The principle of neutrality may be breached if tax incentives distort the types of artworks produced: for example, in theory at least, artists may choose to produce works with popular appeal, which might lend themselves to reproduction, and therefore earn copyright royalties, ${ }^{19}$ rather than avant-garde works, which contribute to cultural expansion and progress. ${ }^{20}$ Furthermore, tax concessions may be inefficient if they allocate tax privileges to any copyright-holders who are already adequately incentivised and rewarded in the market. ${ }^{21}$

After this Introduction, the article is structured as follows: Part II surveys the types of earnings of visual artists to demonstrate how copyright and a tax concession for copyright income is dislocated from artistic practice. New Zealand and Australia's copyright laws are sufficiently similar at a

15 Income Tax Assessment Act 1997 (Cth) [ITAA 1997], s 405.20.

16 ITAA 1997, s 35-10(4)

17 Prebble, above n 3, at 383.

18 See CA1994, s 16.

19 Salvador Dali, Damien Hirst and Jeff Koons, among other artists, have used their artistic practice to become wealthy. They have been very successful in producing outputs that both appeal to the market and lend themselves to commercial exploitation. On Hirst, in particular, see Mark Brown "Tracey Emin: 'Being an artist is about making art, not money'" The Guardian (online ed, Manchester (UK), 28 May 2017). William Hogarth went further; he successfully lobbied for an Act covering engravings that suited his artistic practice. See Mark Rose "Technology and Copyright in 1735: The Engraver's Act" (2005) 21(1) Information Society 63.

20 On the role of avant-garde artworks in advancing culture, see Clement Greenberg (ed) "Avant-Garde and Kitsch" in Art and Culture: Critical Essays (Beacon Press, Boston, 1961) at 10.

21 It is not suggested that artists, who produce replicable artistic works, are, in general, adequately incentivised and rewarded in the market but for any who are, tax concessions are unnecessary and economically inefficient. 
fundamental level to permit discussion of generic copyright law, ${ }^{22}$ and so references are mostly restricted to the Copyright Act 1994 (CA 1994). Part III considers relevant income tax concessions under New Zealand and Australian legislation and compares them to a particular feature of Quebecois law. In part IV, Prebble's prediction of inequity and non-neutrality arising when tax law is ectopic is tested in relation to copyright and related income tax concessions. Recommendations are also made. Part V concludes the article.

\section{COPYRIGHT AND OTHER SOURCES OF VISUAL ARTISTS' INCOMES}

This part of the article surveys the earnings of visual artists in order to assess the relevance of copyright and, therefore, any tax concessions granted to copyright-holders to visual artists' lived experience.

\section{A Copyright-Economic Rights}

A copyright holder in a qualifying work has the exclusive right to issue copies of the work to the public: ${ }^{23}$ examples are provided by a novelist, who earns royalties from sales of their books, and a composer, who permits paid performances or recordings of their songs. Under British-heritage law, copyright subsists in specified types of original works. ${ }^{24}$ The scope of copyright has attracted, inter alia, feminist, ${ }^{25}$ postmodernist, ${ }^{26}$ and anti-formalist ${ }^{27}$ critiques on the grounds that it does not capture many forms of creativity. Creative works that are traditionally imagined and effectuated by women, such as lacework or quilts, have typically fallen outside copyright protection. ${ }^{28}$ Other areas of

22 Copyright legislation in Australia and New Zealand is fundamentally derived from the Imperial Copyright Act 1911 (UK). See Geoff McLay "New Zealand and the Copyright Tradition" in Uma Suthersanen and Ysold Gendreau (eds) A Shifting Empire: 100 Years of the Copyright Act 1911 (Edward Elgar, Cheltenham, 2013) 30; and Robert Burrell "Copyright Reform in the Early Twentieth Century: the View from Australia" (2006) 27(3) JLH 239. However, domestic particularities have been introduced in recent decades.

23 See CA 1994, s 16(1)(b).

24 The categories of qualifying works are: literary, dramatic, musical, or artistic works; sound recordings; films; communication works; or typographical arrangements of published editions. See CA 1994, s 14(1).

25 See for example Emily Chalonor "A Story of Her Own: A Feminist Critique of Copyright Law" (2010) 6(2) I/S: A Journal of Law and Policy for the Information Society 221.

26 See for example Peter Jaszi "Is There Such a Thing as Postmodern Copyright?" (2009) 12 Tul J Tech \& Intell Prop 105.

27 See Justine Pila "An Intentional View of the Copyright Work" (2008) 71(4) MLR 535; and Justine Pila "Copyright and Its Categories of Original Works" (2010) 30(2) OJLS 229.

28 See Carys J Craig "Feminist Aesthetics and Copyright Law: Genius, Value, and Gendered Visions of the Creative Self" in Irene Calboli and Srividhya Ragavan (eds) Protecting and Promoting Diversity with Intellectual Property Law (Cambridge University Press, Cambridge, 2014) Osgoode Legal Studies Research Paper No 42/2014<https://ssrn.com>. 
creativity are also excluded, for example, William Cornish observes "gardening is the greatest art form outside the range of copyright". ${ }^{29}$ Indigenous creative works may also fail to meet copyright law's originality requirement if they follow traditional patterns or are communally-produced works. ${ }^{30}$ Avant-garde artworks may lie outside the copyright definition of an artistic work because they are purely conceptual or are evanescent. ${ }^{31}$ The whole fields of ready-mades, ${ }^{32}$ and appropriation art, ${ }^{33}$ which Robert Shore argues encapsulates all art, ${ }^{34}$ may also be excluded from copyright protection. Furthermore, copyright can be problematic for emerging art forms. ${ }^{35}$

Works of artistic craftsmanship that incorporate the highest degree of skill and ingenuity do not attract copyright, unless they manifest artistic quality. ${ }^{36}$ Conversely, because, in Australasia, a "creative spark" is not unequivocally required for copyright to inure, ${ }^{37}$ the most mundane of commercial texts and graphic works are copyright-protected if they fall within a prescribed category

29 W R Cornish "Authors in Law" (1995) 58 MLR 1 at 11.

30 See for example Miranda Forsyth "Intellectual Property Laws in the South Pacific: Friend of Foe?" (2003) 7(1) Journal of South Pacific Law <www.paclii.org>; Graeme W Austin "Re-treating intellectual property? The Wai 262 proceeding and the heuristics of intellectual property law" (2003-2004) 11 Cardozo J Int'l \& Comp L 333; Daniel J Gervais "Spiritual but Not Intellectual? The Protection of Sacred Intangible Traditional Knowledge" (2003-2004) 11 Cardozo J Int'l \& Comp L 467; and Peter Drahos and Susy Frankel (eds) "Indigenous Peoples' Innovation and Intellectual Property: The Issues" in Indigenous Peoples' Innovation: Intellectual Property Pathways to Development (ANU e press, Canberra, 2012).

31 Simon Stokes Art and Copyright (2nd ed, Hart Publishing, Oxford, 2012) at 53-54.

32 Ready-mades are pre-existing manufactured objects selected by an artist and then accorded the status of artwork. See Michael Clarke Oxford Concise Dictionary of Art Terms (Oxford University Press, Oxford, 2010) at 208 .

33 An appropriation artwork incorporates an existing artwork into a new artwork. At 13.

34 Robert Shore Beg, Steal \& Borrow (Elephant Books, London) at 175.

35 See for example Patricia Search "Electronic Art and the Law: Intellectual Property Rights in Cyberspace" (1999) 32(3) Leonardo 191.

36 See CA 1994, s 2 definition of "artistic work"; and Bonz Group (Pty) Ltd v Cooke [1994] 3 NZLR 216 (HC).

37 The United States Supreme Court held in Feist Publications Inc v Rural Telephone Service Co Inc 499 US 340 (1991) (O'Connor J) at 358 that where "the creative spark is utterly lacking or so trivial as to be virtually nonexistent", a work does not attract copyright. However, the Federal Court of Australia rejected such a requirement of creativity in Desktop Marketing Systems Pty Ltd v Telstra Corporation Ltd (2002) 119 FCR 491, 532 per Lindgren J, which, like Feist, concerned the originality of a telephone directory. In IceTV Pty Limited v Nine Network Australia Pty Limited [2009] HCA 14, 239 CLR 458 at [187]-[188], the High Court of Australia declined to declare Desktop Marketing wrong on the issue of creative spark because it did not need to do so in order to make its decision - IceTV had conceded that the infringed compilation of television programs was an original literary work. Nevertheless, in questioning the compatibility of the decision in Desktop Marketing with long-standing copyright principles, the Court may be seen as having implied that some creative spark is necessary. 
and originate from an identifiable author. Indeed, New Zealand's leading copyright case relates to the protected drawings for the packaging of glue dispensers. ${ }^{38}$

Even when it does subsist in a creative work, copyright has not traditionally served visual art well. As Alfred Steiner observes: ${ }^{39}$

Copyright is designed to deal with mass production. It works well in the context of music, movies, books, and software, where works routinely sell millions of copies. But at least as applied now, copyright breaks down in its approach to art, which is not generally mass produced.

Dick Frizzell is one of the few living New Zealand artists whose works are commonly reproduced. Indeed, his prints can be bought from a discount business stationer. ${ }^{40}$ Less well-known artists may produce, say, postcards to advertise and memorialise an exhibition but an outlet, such as a provincial gallery giftshop, typically charges a seller's fee of up to 50 per cent. Furthermore, if a person commissions an artist to create an artistic work, they, not the artist owns the copyright in the works, unless the parties agree otherwise. ${ }^{41}$

Empirical evidence indicates that copyright has a negligible role in rewarding visual artists. While caution should be exercised in drawing strong conclusions, given the age of the research, a 2003 Creative NZ investigation reported that of 131 visual artists surveyed, none received any copyright income. ${ }^{42}$ More recent research conducted in the United Kingdom, reported that eight per cent of visual artists received income from "Licencing from copyright (IPR) and copyright royalties". 43 Whether the higher percentage is attributable to spatial reasons (for example, the United Kingdom's

38 See Henkel KGaA v Holdfast New Zealand Ltd [2006] NZSC 102, [2007] 1 NZLR 577.

39 Alfred Steiner "A Few Observations on Copyright and Art" (2013) 5(3) Landslide 48 at 48 (footnotes omitted).

This article is concerned with the position of independent visual artists but it may be noted that copyrightprotected works, which include computer programs as literary works, are commonly created within the context of an employment relationship and are therefore owned by employers, typically bodies corporate. See CA 1994, s 21. The employer as first owner is a default rule that may be reversed by contract. However, it is reasonable to expect employers to ensure they own copyright in works created by their employees.

40 See for example "Dick Frizzell Artwork Prints" (2020) Warehouse Stationery <www.warehouse stationery.co.nz>.

41 See CA 1994, s 21(3) and (4) but compare with CA 1968, s 35.

42 "Portrait of the Artist: A Survey of Professional Artists in New Zealand" (2003) Creative NZ $<$ www.creativenz.govt.nz $>$ at 53. However, 5 per cent reported receiving royalties or advances, which suggests the possibility of under-reporting of income derived from intellectual property.

43 "Livelihoods of Visual Artists: 2016 Data Report" (14 December 2018) Arts Council $<$ www.artscouncil.org.uk $>$ at 19 . 
more sophisticated art ecosphere) or temporal (for example, increased web-based sales of prints in the intervening years), copyright directly benefits few visual artists. ${ }^{44}$

\section{B Copyright-Moral Rights}

In addition to the economic privileges associated with the exclusive exploitation rights afforded by copyright, authors also enjoy so-called moral rights. ${ }^{45}$ Elizabeth Adeney identifies "moral rights" as: ${ }^{46}$

specialized legal devices that allow certain creators to control the treatment and presentation of their work

by others. They thereby safeguard the non-economic interests that arise from the creative act.

Authors may, for example, assert their right to be identified as such and may object to derogatory treatment of their works. Moral rights may not be alienated in the way that copyright is transmissible, ${ }^{47}$ but may be waived, ${ }^{48}$ and such a waiver may have some economic value. For example, an employer in the creative industries or education might pay an employee a lump sum in order to waive their moral rights. It is debatable whether such a receipt would be taxable as income. ${ }^{49}$ However, it would not qualify for the income tax concessions analysed here, ${ }^{50}$ and so moral rights will not be considered further in this article.

\section{$C$ Droit de suite}

Simon Stokes describes droit de suite or the resale royalty right (RRR), which permits a visual artist and their heirs to share in the resale price of their works, as "a branch of copyright". ${ }^{51}$ Certainly, the Berne Convention, the principal international copyright treaty, provides for droit de suite as a

44 According to Creative NZ's research, writers, the principal beneficiaries of copyright, only receive 30 per cent of their incomes from "royalties or advances". See Creative NZ, above $\mathrm{n} 42$, at 53.

45 See CA 1994, pt 4.

46 Elizabeth Adeney The Moral Rights of Authors and Performers: An International and Comparative Analysis (Oxford University Press, Oxford, 2006) at 1.

47 CA 1994, s 113.

48 Section 107.

49 Such a payment does not appear to constitute a restrictive covenant (taxable under ITA 2007, s BE 9) or an exit payment (taxable under s BE 10). It would therefore need to fall under the general income provision (s $\mathrm{BE} 1)$ in order to be taxable.

50 ITA 2007, s EB 1 refers to "assigning" or "granting" a copyright interest. Since moral rights may only be waived, not assigned or otherwise transferred or shared, this provision does not appear to apply to compensation for waiver of moral rights.

51 Stokes, above n 31 , at 1. 
voluntarily assumed obligation for party states. ${ }^{52}$ However, droit de suite is substantively different from copyright. The latter relates to the exploitation of immaterial expressions of ideas, and the former to the resales of physical artworks. In fact, droit de suite is designed to compensate visual artists who cannot practically exploit their works through copyright. ${ }^{53}$

Unlike Australia, ${ }^{54}$ New Zealand does not currently operate a droit de suite scheme. Consequently, a New Zealand artist, whose works are resold in Australia, is not eligible for a royalty because national schemes are based on reciprocity. Under the Australian RRR scheme, ${ }^{55}$ most annual payments are in the AUD50-500 range. ${ }^{56}$ According to the UK Arts Council, in 2015 only 2 per cent of UK visual artists earned income from the United Kingdom's RRR scheme. ${ }^{57}$

\section{Public Lending Right}

The public lending right (PLR) allows authors, including illustrators, to receive payment from government to compensate for the free loan of their books by public and other libraries. ${ }^{58}$ NZD2

52 See the Berne Convention for the Protection of Literary and Artistic Works 1161 UNTS 30 (9 September 1886 as completed through the Paris Act of 24 July 1971, as amended on 28 September 1979), art 14ter.

53 See, notably, Albert Vaunois's article in the Chronique de Paris of 25 February 1893, cited by Liliane de Pierredon-Fawcett The Droit de Suite in Literary and Artistic Property (Center for the Law and Arts, Columbia University School of Law, New York, 1991) at 2. See also Directive 2001/84/EC of the European Parliament and of the Council of 27 September 2001 on the resale right for the benefit of the author of an original work of art [2001] OJ L 272, 32-36 preamble at (1)-(5).

54 See Resale Royalty Right for Visual Artists Act 2009 (Cth) (RRRVAA 2009). In New Zealand, the Copyright (Artists Resale Right) Amendment Bill 2008 was introduced by the Labour-led government but was not taken up by the incoming National-led government. It is likely that the European Union would make it a condition of a free trade agreement (FTA) with New Zealand that the latter at least investigate introducing droit de suite, as it did in its FTA with South Korea. See "Korea-EU FTA" (2016) KoreanLII < http://koreanlii.or.kr>.

55 "Royalty" is a term of convenience in relation to RRR schemes. A property holder may charge a royalty for allowing another to use something they own. An artist, who is entitled to an RRR, has no traditional property interest in one of their works once it enters the secondary market (although they can include contractual stipulations governing the first resale), and may have also assigned copyright in the work. (To reiterate, the intellectual property rights in an artistic work are separate from the property rights in the physical copy.) The term droit de suite is derived from French law of immovable property, although artworks are typically movables. However, the artist or their estate has no security interest in the artwork (compare with personal property securities) and no preference in the event of insolvency of the reseller. Furthermore, an RRR cannot be alienated or, under Australian law, waived: see RRRVAA 2009, ss 33 and 34.

56 Copyright Agency "Resale Royalty" (2020) Resale Royalty <www.resaleroyalty.org.au> .

57 Arts Council, above n 43, at 19.

58 See Jim Parker "The public lending right and what it does" Wipo Magazine (online ed, Geneva (Switzerland), June 2018) <www.wipo.int>. In Zealand, the PLR is governed by the Public Lending Right for New Zealand Authors Act 2008; and, in Australia, by the Public Lending Right Act 1985 (Cth). 
million is shared annually between authors. While graphic novels may be an expanding niche, ${ }^{59}$ illustrations are most common in children's books, which account for around 35 per cent of PLR payments. ${ }^{60}$ Few illustrators are, therefore, likely to earn a significant income from PLR. ${ }^{61}$

\section{E Other Sources of Income}

For artists, who create singular artworks, sales in the primary market, including commissioned works, is their principal source of income. ${ }^{62}$ A number of prestigious competitions, such as the Parkin Drawing Prize, the Wallace Art Awards and the Walters Prize, provide significant prize money for select artists. ${ }^{63}$ Creative NZ provides grants, but these tend to be awarded to already well-established artists: for example, a grant may be awarded as a contribution to costs for an overseas residency. ${ }^{64}$ New Zealand artists who exhibit in Scandinavian countries may be paid a stipend to cover their time in setting-up and publicising an exhibition. ${ }^{65}$

The historical custom of patronage of artists by the wealthy or the church, has been modernised and democratised by websites, such as Patreon, ${ }^{66}$ which enable art lovers to fund artists or particular projects. ${ }^{67}$

Visual art practice today is invariably a graduate profession. Some artists are, therefore, able to earn a stable income from teaching, which funds their artwork. According to David Throsby and Virginia Hollister: ${ }^{68}$

59 See Tim Bollinger "Comics and graphic novels" Te Ara | the Encyclopaedia of New Zealand $<$ www.TeAra.govt.nz>

60 See "PLR Payment Statistics" National Library <https://natlib.govt.nz>.

61 Katz Cowley, illustrator of the highly successful Wonky Donkey, might be an exception but no longer resides in New Zealand and so is not eligible for a share in the New Zealand PLR.

62 Creative NZ, above n 42, at 53 reports that visual artists earn 58 per cent of their income from sales of artworks; 14 per cent from project or contract work; and 11 per cent from commissioned works. As revealed in Bambury v Jensen [2015] NZHC 2284, dealer-galleries typically charge commissions of at least 40 per cent.

63 None of the visual artists surveyed by Creative NZ, above n 42, at 53 reported receiving income from prizes.

64 See "Who got funded?" (2020) Creative NZ < www.creativenz.govt.nz>.

65 See Jóna Hlíf Halldórsdóttir "We Pay Artists" (2015) 5(3) Stara.

66 "Create on your own terms" Patreon <www.patreon.com>.

67 Any such "gifts" would almost certainly be taxable as income under ordinary concepts: see ITA 2007, s CA 1(2); and G[raham] v Commissioner of Inland Revenue [1961] NZLR 994 (HC).

68 David Throsby and Virginia Hollister Don't Give up Your Day Job: An Economic Study of Professional Artists in Australia (Australia Council, Canberra, 2003) at 80. 
[O]n average, Australian artists are able to spend just 50 per cent of their time on creative work, having to spend the rest of their time earning income from other sources to meet their basic needs.

Since jobs, which are directly related to artistic practice, such as teaching, are scarce, we can expect many artists to seek casual work, for example, in hospitality.

\section{DIFFERENTIAL TAX TREATMENT}

This part of the article outlines the peak copyright income spreading provision under New Zealand law and problematic features of that concession. In contrast, the more "entopic" features of comparable Australian and Quebecois income tax provisions are identified.

\section{A New Zealand}

New Zealand tax legislation permits some spreading or averaging of certain types of income which may be subject to peaks and troughs. ${ }^{69}$ The concession also applies to patent-holders, ${ }^{70}$ but not to other taxpayers, such as realtors or sportspeople, who commonly experience variations in their earnings.

The spreading provision was first introduced for copyright receipts in $1962,{ }^{71}$ coterminous with new copyright legislation. ${ }^{72}$ This synchronicity appears to be coincidental and it seems more likely that the provision was motivated by a desire to equalise treatment of copyright-holders with that of patent-holders, for whom concessions had been established previously. ${ }^{73}$ The Explanatory Memorandum to the Bill merely stated: "This [concession] is intended to meet the position where the taxpayer receives peak royalties in the period following the first publication of the work." 74 If, for

69 Besides copyright and patent income, spreading applies to income from farming and forestry, inflationindexed investments, land, and employment income of share-holder employees. See ITA 2007, sub-pt EI.

70 It would be unusual, but an artist might be able to register a patent in respect of an artwork. See Michael Blakeney "Patentability and Fine Art" in Jani McCutcheon and Fiona McGaughey (eds) The Research Handbook on Art and Law (Edward Elgar, Cheltenham, 2020) 114. An artist-inventor may also benefit from concessions for peak patent royalties: see, for example, ITA 2007, EI 4. This unlikely possibility is noted but will not be considered further in this article.

71 Introduced by Land and Income Tax Amendment Act (No 2) 1962, s 6 which amended the Land and Income Tax Act 1954. The provision was carried forward into subsequent principal Acts, such as Income Tax Act 1976, s 84; Income Tax Act 1994, s EN 3; and ITA 2007, s EI 3.

72 Copyright Act 1962, repealed by CA 1994.

73 Since a patent is usually an income-producing asset, proceeds from the sale of a patent are at first face capital in nature. (See Dixon J's dissenting opinion in Hallstroms Pty Ltd v FCT (1946) 72 CLR 634 (HCA) on the capital nature of patents.) Land and Income Tax Amendment Act 1945, s 11 included receipts from the disposal of a patent in assessable income. As an apparent compromise, receipts could be spread equally over the current and previous five years of assessment. Receipts from the sale of patents are currently included as income under ITA 2007, s CB 30 and can be spread over the current and following two income years.

74 Land and Income Tax Amendment Act (No 2) 1962. 
example, an author writes a novel over five years, and then licenses publication to a publisher, they will be able to spread the amount received over the current and previous two tax years, rather than experiencing a spike in taxable income in the year of receipt.

The current iteration of the concession, ITA 2007, s EI 3, which is titled "Assigning or granting copyright", provides:

(1) This section applies when a person-

(a) is the author of ... [an] artistic work; and

(b) made the work over a period of more than 1 year; and

(c) receives consideration from-

(i) assigning some or all of the copyright in the work; or

(ii) granting an interest in the copyright by licence.

No different from interpreting any other statutory provision, ${ }^{75}$ the meaning of tax legislation should be "ascertained from its text and in the light of its purpose". ${ }^{76}$ Words take their ordinary meanings. ${ }^{77}$

The Oxford English Dictionary defines "copyright" as: ${ }^{78}$

[t]he exclusive right given by law for a certain term of years to an author, composer, designer, etc. (or his assignee), to print, publish, and sell copies of his original work.

Copyright is, then, a legal concept, despite its commercial relevance, and is currently permitted and governed in New Zealand by the CA 1994.

Neither the ITA 2007 nor the Tax Administration Act 1994 includes a definition of "artistic work", "author" or "copyright". Should officials, courts and others seek to define these terms under income tax law or adopt the meanings under the CA 1994 or broader copyright law? ${ }^{79}$ A comparable interpretative issue arises in relation to the meaning of "employee", a critical term that is partially defined under income tax legislation. ${ }^{80}$ In Bryson v Three Foot Six, ${ }^{81}$ the New Zealand Supreme Court interpreted the definition of "employee" provided in s 5 of the Employment Relations Act 2000.

75 See Commissioner of Inland Revenue v Alcan New Zealand Ltd [1994] 3 NZLR 439 (CA) at 443.

76 Interpretation Act 1999, s 5(1).

77 Mangin v Commissioner of Inland Revenue [1971] NZLR 591 (PC) at 594, approved in Commissioner of Inland Revenue $v$ Alcan New Zealand Ltd, above n 75, at 443.

78 Oxford English Dictionary "copyright, n. (and adj.)" (September 2020) OED Online <www.oed.com> (emphasis added).

79 Each of the terms is used in the Berne Convention for the Protection of Literary and Artistic Works, above $\mathrm{n}$ 52.

80 See ITA 2007, s YA 1.

81 Bryson v Three Foot Six [2005] NZSC 34, [2005] 3 NZLR 721. 
The Inland Revenue Department follows Bryson. ${ }^{82}$ However, because the Supreme Court's interpretation included tests established under previous industrial relations legislation, ${ }^{83}$ it is submitted that the income tax meaning of "employee" is appropriately derived from the concept of employee under employment law but is not bound by the technicalities of a particular Act that is in force at a certain point in time.

It is submitted that a similar approach is appropriate for the relationship between copyright law and income tax. It makes sense for income tax legislation to follow copyright law, if its wishes to privilege copyright royalties, but not to be inappropriately bound by the technicalities of another statute. Nevertheless, the substance of the definition of "artistic work" has been stable in Britishheritage copyright law since the enactment of the Copyright Act 1911 (UK).

The key issue lies with the taxpayer receiving copyright income, whether that receipt emanates from New Zealand or from a jurisdiction with a different copyright tradition or rules. ${ }^{84}$ For example, if a taxpayer receives a royalty from an artistic work that would not qualify as original under New Zealand law because of appropriation but does qualify in the United States because of its doctrine of fair use, ${ }^{85}$ the receipt should qualify for the s EI 3 concession.

Notwithstanding its apparent and criticisable importation of copyright doctrine, ITA 2007, s EI 3 represents an example of income tax legislation seeking, albeit to a limited extent and for the benefit of a select class of taxpayers, to reflect the reality of earning income from artistic creation - the income-earning activity is unlikely to take place in one discrete year of assessment. This attempt to bring law closer to fact is, however, practically irrelevant if an artist does not earn copyright income.

82 See "Interpretation Guideline: IG 11/01 Income Tax; Goods and Services Tax - Determining Employment Status for Tax Purposes (Employee or Independent Contractor?)" (8 March 2016) Inland Revenue Department $<$ www.taxtechnical.ird.govt.nz $>$.

83 See, notably TNT Worldwide Express Ltd v Cunningham [1993] 3 NZLR 681 (CA), which arose from the Employment Contracts Act 1991.

84 Normal source and tax residency rules apply. For example: A New Zealand tax resident who receives a copyright payment from the United Kingdom would be taxed in New Zealand but a British visitor who receives a royalty from the United Kingdom would not be taxed in New Zealand. See ITA 2007, s BD 1(4).

85 On fair use, see N Weinstock Netanel "Making Sense of Fair Use" (2011) 15 Lewis \& Clark L Rev 715. On Australia's consideration of adopting fair use, see Australian Law Reform Commission Copyright and the Digital Economy Discussion Paper 79 (ALC DP 79, 2013) <www.alrc.gov.au>; Australian Government Intellectual Property Arrangements: Productivity Commission Inquiry Report Overview and Recommendations (2016) <www.pc.gov.au>; and Australian Government, Department of Communication and the Arts Copyright Modernisation Consultation (2018) <www.communications.gov.au>. 


\section{B Australia}

ITAA 1997, s 405.20(6) is substantially similar to ITA 2007, s EI 3 and will not be considered further. However, two other features of the Australian income tax legislation are currently relevant: averaging of other forms of assessable professional income and immediate setting-off of losses.

\section{Assessable professional income}

Assessable professional income for an income year is the sum of a taxpayer's assessable income for that period derived from providing services relating to their activities as a special professional. ${ }^{86}$ A "special professional" includes "the author of a literary, dramatic, musical or artistic work" and "the inventor of an invention". 87

\section{Exception to non-commercial loss rules}

ITAA 1997, div 35 prevents individuals' losses from non-commercial business activities being offset against other assessable income in the year the loss is incurred; rather the loss is deferred. However, an exception applies to business activity that is a professional arts business and the taxpayer's assessable income for that year (except any net capital gain) from other sources that does not relate to that activity is less than AUD40,000. ${ }^{88} \mathrm{~A}$ "professional arts business" is a business the taxpayer carries on "as the author of a literary, dramatic, musical or artistic work". ${ }^{89}$ A note to s 35 10(5) explains:

The expression 'author' is a technical term from copyright law. In general, the 'author' of a musical work is its composer and the 'author' of an artistic work is the artist, sculptor or photographer who created it.

\section{Interpretation}

The Explanatory Memorandum to the Taxation Laws Amendment Bill 1987 stated in relation to the forerunner of div 405 :

'artist' is defined as meaning the author of an artistic work. By referring to an 'author of an artistic work' the definition is intended to pick up the meaning of those terms as they are used in the Copyright Act 1968 .

86 ITAA 1997, s 405.20. For a plain language guide, see "Income Averaging for Special Professionals 2018" (2018) Australian Taxation Office $<$ www.ato.gov.au $>$.

87 Section 405.25. It is notable that inventors do not necessarily hold patents in their inventions and so patents law is not impliedly incorporated into the Act in the way that copyright law is introduced by the use of terms of art of copyright law.

88 Section 35-10(4).

89 See s 35-10(5). 
The adoption of the copyright conception of an artist, which, to reiterate, includes the drafters of the most mundane commercial drawings but excludes many avant-garde artists, raises the question whether resale royalties - or even the sale of physical artworks - fall within the ambit of div 405 . However, such an unusual outcome could not have been intended and the provision can be interpreted so as to avoid that outcome.

The absence from the text of the word "original" - a critical copyright consideration - indicates that a broader concept of creation than that of copyright legislation is covered by the income tax legislation. For example, a person who copies a substantial part of another work would not qualify as the author of an original copyright-protected work however creative their thinking and skilful their craftsmanship. Currently, unlike the United States, which employs a broad fair use principle, Australian and New Zealand copyright statutes do not recognise such transformative works as original artistic works in their own right. Furthermore, indigenous artworks, which may fail the copyright originality test, may qualify for income tax concessions. However, if the copyright understanding of artist (derived from artistic work) is strictly followed, creators of works of artistic craftsmanship would still not qualify unless they produce works that manifest artistic merit. ${ }^{90}$

Does "artistic work" for the purposes of s 35-10(4) take the CA 1968 meaning? If so, "professional arts business" might arguably be restricted to copyright-generating artistic activity. RRR may apply to a wider range of artefacts than copyright-protected artistic works. This seems unlikely. It is more plausible that the drafters used "author" as a convenient shorthand to identify different types of creative practitioners and intended no such restriction.

According to an Australian Taxation Office (ATO) ruling, "the term 'art work(s)' is used to describe the product or services produced as a result of activities undertaken during the course of a 'professional arts business"'. ${ }^{91}$ In fact, the ruling - no doubt wisely, since "art" is notoriously difficult to identify ${ }^{92}$ - does not seek to define what "arts" means in the phrase "professional arts business" but rather what "business" means. In other words, it considers how, for example, the common law principles for distinguishing a business from a hobby apply in the context of the arts. It seems likely

90 Excluding works of artistic craftsmanship that do not manifest artistic quality would be consistent with a distinction first drawn in the early Renaissance between artisans, such as masons, and artists, including sculptors. See Erin J Campbell "Artisans, Artists and Intellectual" (2000) 23(4) Art History 622. Before then, master craftspeople, as members of guilds, produced both artworks and artisanal works. See Rudolf Wittkower and Margot Wittkower Born Under Saturn: The Character and Conduct of Artists: A Documented History from Antiquity to the French Revolution (WW Norton, New York, 1963) at 9.

91 Australian Tax Office "TR 2005/1 Income tax: carrying on business as a professional artist" (2005) $<$ www.ato.gov.au>.

92 "One of the most elusive of the traditional problems of human culture [is] the nature of art." Richard Wollheim Art and Its Objects (2nd ed, Cambridge University Press, Cambridge, 1980) at 1. 
that the ATO would adopt a common sense, ${ }^{93}$ rather than a restrictive copyright, conception of artist as author.

The Acts Interpretation Act 1901 (Cth) s 15AC refers to the use of extrinsic materials in ascertaining the ordinary meaning of a word used in a statute but another Act does not constitute an item of extrinsic material. And so, we cannot simply assume that the definitions provided in CA 1968 apply in ITA 1997. Nevertheless, as French CJ observed in International Finance Trust Cos Ltd v NSW Crime Commission, ${ }^{94}$ anyone interested in a statute is "generally entitled to rely upon the ordinary sense of the words that Parliament has chosen." 95 Likewise, in Alcan (NT) Alumina Pty L-td $v$ Commissioner of Territory Revenue, French CJ, having established that the starting point in considering the question of construction is "the ordinary and grammatical sense of the statutory words to be interpreted having regard to their context and legislative purpose", ${ }^{96}$ approved the approach to interpretation that Gaudron J characterised in Corporate Affairs Commission (NSW) v Yui as "those who are subject to the law's commands are entitled to conduct themselves on the basis that those commands have meaning and effect according to ordinary grammar and usage." 97 The ordinary usage of copyright terms is derived from copyright legislation and judicial interpretation of it. Furthermore, notes and examples form part of the ITAA $1997,{ }^{98}$ and so the note to ITAA $1997 \mathrm{~s} 35-10(5)$ on the meaning of "author", strongly indicates incorporation of copyright doctrine but not necessarily its technicalities.

\section{Quebec}

Quebec provides a deduction of up to CAD60,000 (about NZD71,350) for copyright income, including public lending rights, earned by professional artists. ${ }^{99}$ Currently, there is no droit de suite at provincial or federal levels in Canada. ${ }^{100}$

93 See John Middleton "Statutory Interpretation: Mostly Common Sense?" (2017) 40(2) MULR 626

94 International Finance Trust Cos Ltd v NSW Crime Commission [2009] HCA 49, (2009) 240 CLR 319 at 349.

95 At 349

96 Alcan (NT) Alumina Pty L-td v Commissioner of Territory Revenue [2009] HCA 41, (2009) 239 CLR 27 at [4].

97 Corporate Affairs Commission (NSW) v Yui (1991) 172 CLR 319 at 340. For a full discussion of these decisions, see Middleton, above $\mathrm{n} 93$.

98 See ITAA 1997, s 2-45; Acts Interpretation Act 1901 (Cth), s 13.

99 Taxation Act, CQLR c I-3, s 726.26.

100 Scott Simms, a Liberal party MP, introduced the private member's Bill C-516 Artist's Resale Right Act An Act to amend the Copyright Act (artist's resale right) to the Canadian Parliament in 2013 and 2015. The Bill has not been enacted. 
The Taxation Act, CQLR c I-3, s 346.0.1 also provides for a special deduction by professional artists for contributions to a qualifying income-averaging annuity. "Professional artist" is defined in s 7 of Act respecting the professional status of artists in the visual arts, arts and crafts and literature, and their contracts with promoters, CQLR c S-32.01, namely:

Every creator in the field of visual arts, arts and crafts or literature has the status of a professional artist if

(1) he declares himself to be a professional artist;

(2) he produces works on his own behalf;

(3) his works are exhibited, produced, published, presented in public or marketed by a promoter;

(4) he has been recognized by his peers as a professional artist by way of an honourable mention, an award, a prize, a scholarship, an appointment to an adjudication committee or an invitation to participate in a salon or by any other similar means.

Furthermore, an artist who is a professional member of a recognised association "is presumed to be a professional artist". ${ }^{101}$ In terms of s 1 , "This Act applies to self-employed artists who create works in the fields of visual arts, arts and crafts ...".

Although the provision is also a concession extended to copyright income, the statutory conception of the artist is different from that of an author as a copyright-holder or a person carrying on a professional arts business, and may be likened to the institutional theory of art associated with, in particular, George Dickie. ${ }^{102}$ According to Dickie, the institutional approach encapsulates "the ideas that works of art are art as the result of the position they occupy within an institutional framework or context". ${ }^{103}$ By contemplating an artist in the context of the institutional art world, the Quebecois legislation not only excludes copyright holders in mundane, commercial designs but specifically targets genuine artists for concessions.

This article does not argue for adoption of the Quebecois concessions for copyright income but supports the attempt by lawmakers to engage with the true nature of visual artistic practice, rather than importing copyright concepts.

\section{DISCUSSION}

Following Prebble's concept of tax ectopia, this article seeks to reveal the dissonance between the artistic activities taken into account by lawmakers, which are manifest in copyright and income tax

101 Act respecting the professional status of artists in the visual arts, arts and crafts and literature, and their contracts with promoters, CQLR c S-32.01, s 8.

102 See George Dickie Aesthetics, An Introduction (Pegasus, New York, 1971) for his first expression of ideas on an institutional approach to art.

103 George Dickie "The New Institutional Theory of Art" in Peter Lamarque and Stein Haugon Olsen (eds) Aesthetics and the Philosophy of Art: The Analytic Tradition, An Anthology (John Wiley \& Sons, Hoboken (NJ), 2019) 15 at 15. 
legislation, and the typical lived experience of visual artists. To reiterate, Prebble demonstrates that, when facts and tax law are misaligned, inequities and non-neutrality arise. Applying usual tax criteria, this part of the article demonstrates why current concessions for copyright income are non-neutral and unfair for typical visual artists. Recommendations are then made.

\section{A Usual Tax Criteria}

Tax commentators broadly agree that taxes should be fair and efficient. ${ }^{104}$ Other desirable characteristics include convenience, ${ }^{105}$ neutrality, ${ }^{106}$ and policy consistency. ${ }^{107}$

\section{B Application of Usual Tax Criteria}

This section briefly applies usual tax criteria to the income tax concessions discussed in Part III in order to highlight their ectopic qualities.

\section{Income averaging}

(a) Equity

In New Zealand, the averaging provisions do not relate to all artistic activity, but only to creative activity that leads to the generation of copyright income. Since visual artists typically do not earn copyright (or droit de suite in New Zealand). Income averaging only benefits the select group of artists whose works are commercially reproduced. To reiterate, the concept of "artistic work" under copyright legislation is notorious for its exclusion of certain types of creative activity. For example, unlike, say, mundane commercial drawings, artisanal works do not qualify for copyright protection unless they manifest undefined artistic quality. As the famous George Hensher Ltd v Restawile Upholstery (Lanes) Ltd (George Hensher) case amply demonstrated, ${ }^{108}$ judges have found it particularly challenging to determine whether a work of artistic craftsmanship does indeed manifest artistic quality - five different opinions were given by the House of Lords, none of which was fully persuasive.

An artist who invests more than one year in creating a singular artwork does not enjoy averaging concessions. As the ITA 2007 stands, if New Zealand were to introduce a droit de suite, peak royalty payments would also not attract averaging.

104 See for example Adam Smith An Inquiry Into the Nature and Causes of the Wealth of Nations (Encyclopaedia Britannica, Chicago, 1952, first published 1776) at 361.

105 At 362

106 Carl S Shoup Public Finance (Aldine Pub Co, London, 1969) at 21.

107 Ken Henry (chair) Principles and Features of a New System (2010) <http://taxreview.treasury.gov.au>.

108 George Hensher Ltd v Restawile Upholstery (Lanes) Ltd [1976] RPC 31 (HL). 
Since the Australian non-commercial loss exception does not apply if an artist has income in excess of AUD40,000 from other sources, that concession also favours the most commercially successful artists who are able to work fulltime in pursuing their artistic practice. As Throsby and Hollister note, artists typically work half their time earning other types of income. ${ }^{109}$

(b) Neutrality and efficiency

The Organization of Economic Cooperation and Development states: ${ }^{110}$

Taxation should seek to be neutral and equitable between forms of business activities. A neutral tax will contribute to efficiency by ensuring that optimal allocation of the means of production is achieved. A distortion, and the corresponding deadweight loss, will occur when changes in price trigger different changes in supply and demand than would occur in the absence of tax. In this sense, neutrality also entails that the tax system raises revenue while minimising discrimination in favour of, or against, any particular economic choice. This implies that the same principles of taxation should apply to all forms of business, while addressing specific features that may otherwise undermine an equal and neutral application of those principles.

In New Zealand, according to the IRD, "Tax neutrality is a core part of New Zealand's general BBLR [broad base low rate] approach to taxation."111

Providing tax concessions to select members of a profession is economically inefficient. Those visual artists who receive significant copyright income are already incentivised to produce by exclusive exploitation rights. ${ }^{112}$ The income tax system does not need to provide further benefits. Moreover, because treatment of copyright-earning and other visual artists is not even-handed, a perverse incentive might exist for artists to produce popular, rather than avant-garde works. That incentive might be inherent in the market system, but income tax should not potentially exacerbate it.

(c) Consistency

If two pieces of legislation enacted in the same jurisdiction use a particular word, one might reasonably expect administrators and courts to give the same meaning, mutatis mutandis, to the word when interpreting the statutes. However, different interpretations may be necessary to give proper meaning to ostensibly the same word in different contexts. It is submitted that importation of copyright

109 Throsby and Hollister, above n 68, at 80. See also Creative NZ, above n 42 .

110 OECD Addressing the Tax Challenges of the Digital Economy, OECD/G20 Base Erosion and Profit Shifting Project (OECD Publishing, Paris, 2014) at 30.

111 See Policy and Strategy, Inland Revenue, and the Treasury Taxation of employee share schemes - An officials' issues paper (May 2016) <http://taxpolicy.ird.govt.nz> at 6.

112 On the incentive argument, see Seana Valentine Shiffrin "The Incentives Argument for Intellectual Property Protection" in Axel Gosseries, Alain Marciano and Alain Strowel (eds) Intellectual Property and Theories of Justice (Palgrave Macmillan, Basingstoke (UK), 2008). 
terminology into income tax legislation is unnecessary and unhelpful. For example, ITAA 1997 refers to inventor, rather than patent-holder. If income tax legislation used, say, "creator", rather than "author", artists would be more accurately identified (but still not benefit from copyright concessions).

\section{Recommendations}

Generally, it is not obvious why certain types of receipt, including peak copyright, should benefit from spreading or averaging, ${ }^{113}$ when others, such as sales commissions, do not. A discrete year of assessment may not reflect how receipts are generated in practice; nevertheless, most forms of income are taxed on this basis, and it appears unfair and non-neutral for tax law to differentiate in this way. It is suggested that spreading should either not apply to any income or to all forms of income that fluctuate from year to year.

This article has a narrow interest in the equitable and neutral treatment of visual artists, of whom, only a small proportion earn copyright income. The Australian approach of extending the averaging concession to "special professionals" is eminently worthy of emulation but remains unnecessarily tied to copyright concepts. It is therefore recommended that the Quebecois definition of "professional artist" should be used to identify who, among visual artists, should benefit from spreading income from a professional arts business.

\section{CONCLUSION}

Starting from Prebble's basic concept of ectopic dislocation of fact and law, this article has argued that the general dissonance of income tax provisions from the facts to which they relate is compounded for most visual artists when income from copyright is privileged. Income tax concessions for the members of a small elite of visual artists, who create visual artworks but also earn copyright income from replication of those things are inequitable, inefficient and potentially distort behaviour. Australia's concepts of special professional and professional arts business are markedly fairer but are still unnecessarily linked to copyright terminology and doctrine. While Quebecois law is also flawed in privileging artists' copyright income, it is more entopic inasmuch as it seeks to define an artist by reference to art world concepts and what artists actually do. It is hoped that this modest and highly particular article is an appropriate tribute to Professor Prebble's remarkable contribution to taxation studies.

113 For example, the Income Tax Act 2007 (UK), s 461 permits spreading of patent royalties and Income Tax (Trading and Other Income) Act 2005, s 221 provides for averaging of income farming, aquaculture and creative work. 